\title{
Highly Deviated Asymmetric Division in Very Low Proportion of Mycobacterial Mid-log Phase Cells
}

\author{
Srinivasan Vijay, Nagaraja Mukkayyan and Parthasarathi Ajitkumar*
}

Department of Microbiology and Cell Biology, Indian Institute of Science, Bangalore - 560012, Karnataka, India.

\begin{abstract}
In this study, we show that about 20\% of the septating Mycobacterium smegmatis and Mycobacterium xenopi cells in the exponential phase population divide asymmetrically, with an unusually high deviation $(17 \pm 4 \%)$ in the division site from the median, to generate short cells and long cells, thereby generating population heterogeneity. This mode of division is very different from the symmetric division of the majority (about $80 \%$ ) of the septating cells in the Mycobacterium smegmatis, Mycobacterium marinum, and Mycobacterium bovis BCG exponential phase population, with $5-10 \%$ deviation in the division site from the mid-cell site, as reported by recent studies. The short cells and the long cells further grew and divided to generate a population. We speculate that the generation of the short cells and the long cells through the highly deviated asymmetric division in the low proportions of mycobacterial population may have a role in stress tolerance.
\end{abstract}

Keywords: Asymmetric cell division, Mycobacterium smegmatis, Mycobacterium xenopi, nucleoid, short cell.

\section{INTRODUCTION}

Cell division in mycobacteria occurs by binary fission, as in most of the rod-shaped bacteria. Several studies have documented different aspects of mycobacterial cell division [1]. Recent studies have shown that the binary fission in the majority (about $80 \%$ of the septating cells) of Mycobacterium smegmatis, Mycobacterium marinum, and Mycobacterium bovis BCG population is symmetric but with minor $(5-10 \%)$ deviation in the division site from the median [2-4], but with corrective mechanisms to generate predominantly equal sized daughter cells [3]. While these studies were focused on the mode by which the majority (80\%) of the septating M. smegmatis, M. marinum, and M. bovis BCG cells divided, the mode of division of the cells in the remaining low proportion $(20 \%)$ of the septating mycobacterial cells in the population remained unknown. Therefore, the present study was initiated to find out how the M. smegmatis (saprophyte) and Mycobacterium xenopi (pathogen) cells in the low proportions of mycobacterial population divided.

Transmission and scanning electron microscopy and fluorescence microscopy of septum-stained live and fixed cells were used to find out whether cells were present with the septum deviated significantly more than the $5-10 \%$ found in the majority of the cells in the population. After ascertaining the presence of cells with highly deviated asymmetric septum, the corresponding highly deviated asymmetric constriction and division were verified using live cell timelapse imaging of the division process. Subsequently,

*Address correspondence to this author at the Department of Microbiology and Cell Biology, Indian Institute of Science, Bangalore-560012, India;

Tel: 91-80-22932344; Fax: 91-80-23602697;

E-mail: ajit@mcbl.iisc.ernet.in the differences in the mode of division of the cells in the minority population, as compared to the features of the symmetric division with minor deviation of the cells in the majority of the population, were documented. The possible physiological significance of the highly deviated asymmetric division in the minority population was then discussed.

\section{MATERIALS AND METHODS}

\section{Bacterial Strains and Culture Conditions}

M. smegmatis $\mathrm{mc}^{2} 155$ [5] and $M$. xenopi [6] cells (obtained from the National JALMA Institute for Leprosy \& Other Mycobacterial Diseases, Agra, India) were grown in Middlebrook $7 \mathrm{H} 9$ medium with or without $0.05 \%$ Tween 80 , as the case may be, at $37^{\circ} \mathrm{C}$ with shaking at $170 \mathrm{rpm}$, till $\mathrm{OD}_{600 \mathrm{~nm}}$ of the culture reached 0.60 (mid-log phase).

\section{Transmission and Scanning Electron Microscopy}

Transmission electron microscopy (TEM) of M. smegmatis and $M$. xenopi cells was performed, as described [7], but with minor modifications [8]. For scanning electron microscopy (SEM), mid-log phase M. smegmatis cells were harvested, washed once with $1 \mathrm{x}$ PBS, fixed with $2 \%$ glutaraldehyde, treated with $0.5 \%$ osmium tetroxide for $2 \mathrm{hrs}$, dehydrated in ethanol series, $30 \%, 50 \%, 70 \%$, and $100 \%$. The samples were sputter-coated with gold and observed under SIRION scanning electron microscope at $4 \mathrm{kV}$, and the images were captured.

\section{Staining and Detection of Septum and Nucleoid in Fixed and Live Cells}

Vancomycin-BODIPY (VBP) was used to stain the septum of live cells, as described [9-11]. One $\mu \mathrm{g} / \mathrm{ml}$ of VBP (in PBS) was added to the cells and incubated with shaking 
at $170 \mathrm{rpm}$ for $3 \mathrm{hrs}$ at $37^{\circ} \mathrm{C}$. The cells were then adhered to poly-L-lysine coated slides for observation under Zeiss AXIO Imager M1 microscope. For staining with WGA-Alexa488 $(2 \mu \mathrm{g} / \mathrm{ml}$ in 1x PBS) [12], the cells were fixed in $4 \%$ para formaldehyde, adhered to poly-L-lysine coated slides, washed with $1 \mathrm{x}$ PBS for $1 \mathrm{~min}$, treated with lysozyme $(2 \mathrm{mg} / \mathrm{ml})$ for $15 \mathrm{~min}$, washed thrice with 1x PBS for $1 \mathrm{~min}$ each, stained for $15 \mathrm{~min}$, mounted on 90\% glycerol, and observed. DAPI staining for nucleoid was performed using $0.5 \mu \mathrm{g} / \mathrm{ml}$ of DAPI in 1x PBS with $0.1 \%$ Triton-X100 for $5 \mathrm{~min}$, and washed thrice with $1 \mathrm{x}$ PBS for 1 min each time. The cells were mounted in $90 \%$ glycerol and observed. A large number of septum-stained cells were analysed using fluorescence microscopy (FM).

\section{Documentation of Time-Lapse Live Cell Division (LCM)}

Live cell time-lapse microscopy of the asymmetric division of M. smegmatis cells $(\mathrm{n}=50)$ was performed in low melting point agarose $(1.5 \%$ in Middlebrook $7 \mathrm{H} 9$ medium) pads, as described $[13,14]$, but with minor modifications [15], with Z-stacking at $37^{\circ} \mathrm{C}$. The cells were observed for about 8-9 hrs (for more than two generations), by taking DIC images at every $10 \mathrm{~min}$ time interval. The data were analysed and the cell length and cell constriction were determined on the images, using Axio vision 4 software.The tracking of the live cell time-lapse imaging movies was performed using the ImajeJ version $1.43 \mathrm{~m}$ [16].

\section{RESULTS}

\section{Ultrastructural Analyses Reveal Cells with Highly Deviated Septum/Constriction}

Using transmission and scanning electron microscopy (TEM and SEM), a large number of cells in the mid-log phase population were first screened for the presence of cells with division site position deviated more than that shown by the majority of the cells in the population. The position of the division site (septum/constriction), when deviated by more than $10 \%$ from the mid-cell site, irrespective of the sizes of the mother cells, was considered highly deviated asymmetric division in our studies. This higher cut-off was set up in order to differentiate the major deviation in the asymmetric septum/constriction position of the cells in the minority population from the minor $5-10 \%$ deviation in the symmetric division of the cells in the majority population ( $80 \%$ of septating cells) of mycobacteria, reported recently [2-4].

Using transmission electron microscopy (TEM) imaging, examination of a large number of mid-log phase M. smegmatis cells $(\mathrm{n}=1000)$ showed that about $20 \%$ of the $15 \%$ septating cells $(\mathrm{n}=150$ septating cells $)$ possessed highly deviated asymmetric septum, which divided the mother cell into a short cell portion and a long cell portion (Fig. 1A-D). The ' $\mathrm{V}$ ' shaped cells, which undergo typical 'snapping post-fission' mode of mycobacterial division $[11,17]$, were also found (Fig. 1D). Cells, which were at the initiation stage of septum formation (Fig. 1E) and towards the completion of the septum constriction (Fig. 1F), also could be observed. Similarly, screening of a large number of mid-log phase M. xenopi cells $(\mathrm{n}=500)$ showed about $30 \%$ of the $15 \%$ septating cells $(\mathrm{n}=75$ septating cells $)$ having highly deviated asymmetric septum (Fig. 1G, H). Nucleoid was present in both the short and the long portions, on either side of the highly deviated asymmetric septum $(n=150$ septating cells) (Fig. 1A-H). Scanning electron microscopy (SEM) imaging also showed the presence of M. smegmatis cells, with unusually deviated asymmetric constriction (Fig. 1I-M), undergoing typical 'snapping post-fission' mode of mycobacterial division $[11,17]$. Majority of the exponential phase septating M. smegmatis cells (80\%) and M. xenopi cells $(70 \%)(\mathrm{n}=150$ septating cells in each case $)$ possessed symmetrically placed septum with minor deviation (Fig. 1N, $\mathbf{O}$ and $\mathbf{P}, \mathbf{Q}$ ).

Measurement of the lengths of the short and the long portions of the $M$. smegmatis and $M$. xenopi cells with asymmetric septum, showed notable size difference of $1.71 \pm 0.56 \mu \mathrm{m}$ and $0.95 \pm 0.74 \mu \mathrm{m}$, respectively $(\mathrm{n}=50$ septating cells in each case) (Table 1). This amounted to 17 $\pm 4 \%$ and $20 \pm 6 \%$ deviation in the septum position from the mid-cell site, for $M$. smegmatis and $M$. xenopi cells, respectively (Fig. 2). These measurements indicated high extent of deviation in the position of the septum in the low proportions of cells in these mycobacterial species. On the contrary, the symmetrically placed septum in the majority of the exponential phase $M$. smegmatis cells $(80 \%)$ and $M$. xenopi cells $(70 \%)(\mathrm{n}=150$ septating cells in each case $)$ showed minor deviation of $5 \pm 5 \%$ and $5 \pm 3 \%$, respectively $(\mathrm{n}=50$ septating cells in each case), from the median (Fig. 2). This is within the 5-10\% deviation reported for the majority of the septating cells in the $M$. smegmatis population [2-4]. The average lengths of the M. smegmatis cells with highly deviated asymmetric septum $(6.09 \pm 1.30$ $\mu \mathrm{m} ; \mathrm{n}=50$ septating cells) and symmetric septum with minor deviation $(6.00 \pm 1.13 \mu \mathrm{m} ; \mathrm{n}=50$ septating cells $)$ were comparable (Table 1). Similarly, the average lengths of the $M$. xenopi cells with highly deviated asymmetric septum $(2.31 \pm 1.20 \mu \mathrm{m} ; \mathrm{n}=50$ septating cells $)$ and symmetric septum with minor deviation $(1.66 \pm 0.72 \mu \mathrm{m} ; \mathrm{n}=50$ septating cells) were comparable (Table 1). Since the features of highly deviated asymmetric cell division of M. smegmatis and M. xenopi cells were comparable, further experiments were performed with M. smegmatis cells only.

\section{Septum Staining of Live and Fixed Cells Shows Cells with Highly Deviated Septum}

Using fluorescence microscopy of septum-stained live and fixed cells, a large number of cells in the mid-log phase population were first screened for the presence of cells with highly deviated septum position. Vancomycin-BODIPY (VBP) staining [9-11] of septum of mid-log phase live $M$. smegmatis cells $(\mathrm{n}=50$ septating cells $)$ showed the presence of highly deviated asymmetric septum (Fig. 3A). WGA-Alexa 488 staining of peptidoglycan [12] of the mid$\log$ phase fixed $M$. smegmatis cells $(\mathrm{n}=50$ septating cells $)$ also showed highly deviated asymmetric septum (Fig. 3B). As found in TEM data, there was considerable difference between the sizes of the short and the long portions of the 

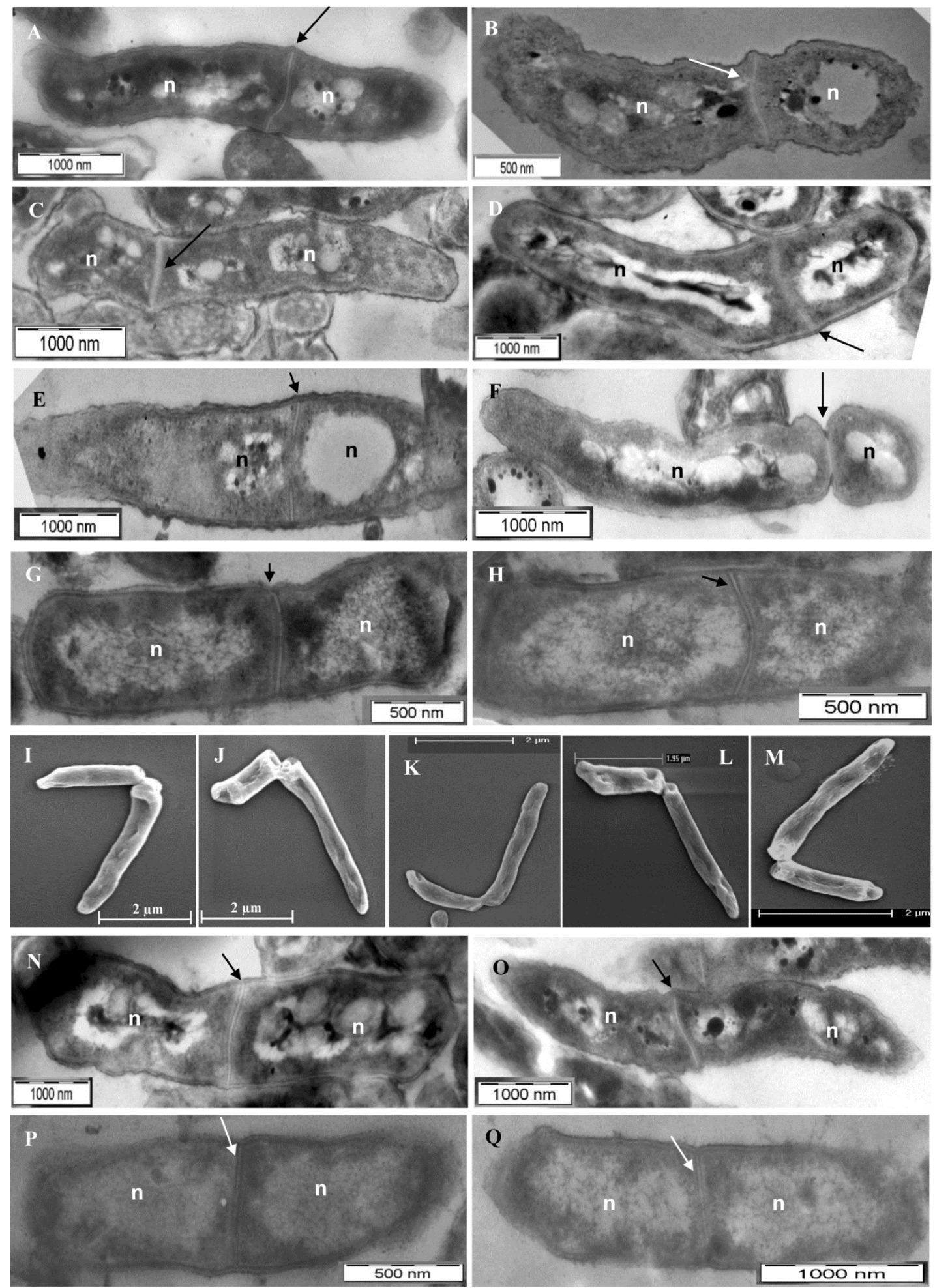

Fig. (1). TEM and SEM imaging of mid-log phase $M$. smegmatis and M. xenopi cells with highly deviated asymmetric septum/ constriction or symmetric septum. (A-D) TEM images of $M$. smegmatis cells with highly deviated asymmetric septum. (D) M. smegmatis cell undergoing 'snapping post-fission' mode of highly deviated asymmetric division. (E) M. smegmatis cell at the initiation of the septum formation. (F) M. smegmatis cell close to the completion of the asymmetric septum constriction. (G, H) M. xenopi cells with highly deviated asymmetric septum. (I-M) SEM images of $M$. smegmatis cells with 'snapping post-fission' mode of highly deviated asymmetric division. (N, O) M. smegmatis cells with symmetric septum with minor deviation. (P, $\mathbf{Q})$ M. xenopi cells with symmetric septum with minor deviation. Arrow indicates the position of the highly deviated asymmetric septum or constriction, or symmetric septum with minor deviation, in the septum position from the mid-cell site (see Table 1). $\mathrm{n}$ indicates nucleoid. 
Table 1. Sizes of the asymmetrically and symmetrically dividing M. smegmatis and M. xenopi cells.

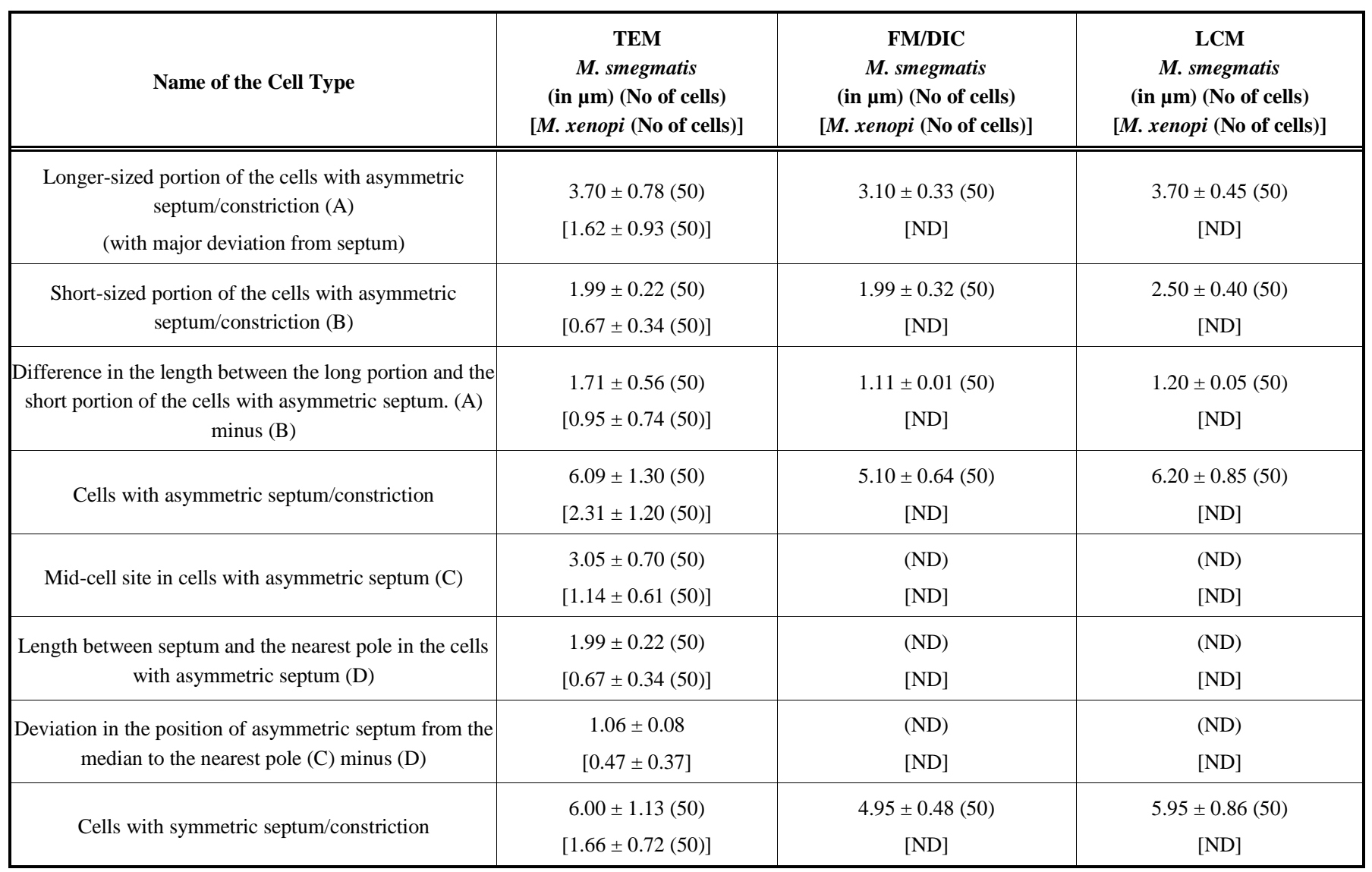
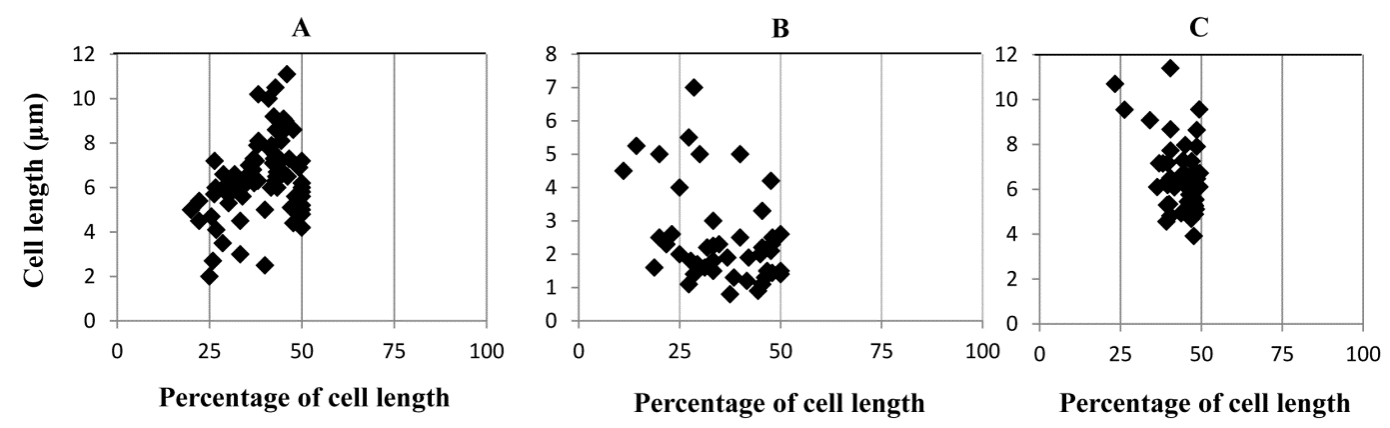

\begin{tabular}{|l|c|c|}
\hline Cell type & $\begin{array}{l}\text { Extent of deviation in the } \\
\text { septum position from the } \\
\text { median measured from TEM } \\
\text { images (n) }\end{array}$ & $\begin{array}{l}\text { Extent of deviation in the } \\
\text { constriction position from } \\
\text { the median measured from } \\
\text { live cell DIC images (n) }\end{array}$ \\
\hline $\begin{array}{l}\text { Asymmetrically dividing } M \text {. smegmatis cell } \\
\text { with major deviation in daughter cell lengths }\end{array}$ & $17 \pm 4 \%(50)$ & $12 \pm 5 \%(50)$ \\
\hline $\begin{array}{l}\text { Symmetrically dividing M. smegmatis cell } \\
\text { with minor deviation in daughter cell lengths }\end{array}$ & $5 \pm 5 \%(50)$ & $3.6 \pm 2 \%(50)$ \\
\hline $\begin{array}{l}\text { Asymmetrically dividing } M \text {. xenopi cell with } \\
\text { major deviation in daughter cell lengths }\end{array}$ & $20 \pm 6 \%(50)$ & ND \\
\hline $\begin{array}{l}\text { Symmetrically dividing } M . \text { xenopi cell with } \\
\text { minor deviation in daughter cell lengths }\end{array}$ & $5 \pm 3 \%(50)$ & ND \\
\hline
\end{tabular}

Fig. (2). Position of the septum and constriction in the highly deviated asymmetrically dividing M. smegmatis and M. xenopi cells. $(A, B)$ Placement of septum with respect to cell length from the TEM images of $M$. smegmatis and M. xenopi cells, respectively $(\mathrm{n}=50$ cells with septum). (C) Position of the constriction in M. smegmatis cells from live cell time-lapse images. ( $\mathrm{n}=50$ cells with constriction). The average values from (A-C) have been tabulated and shown below. 

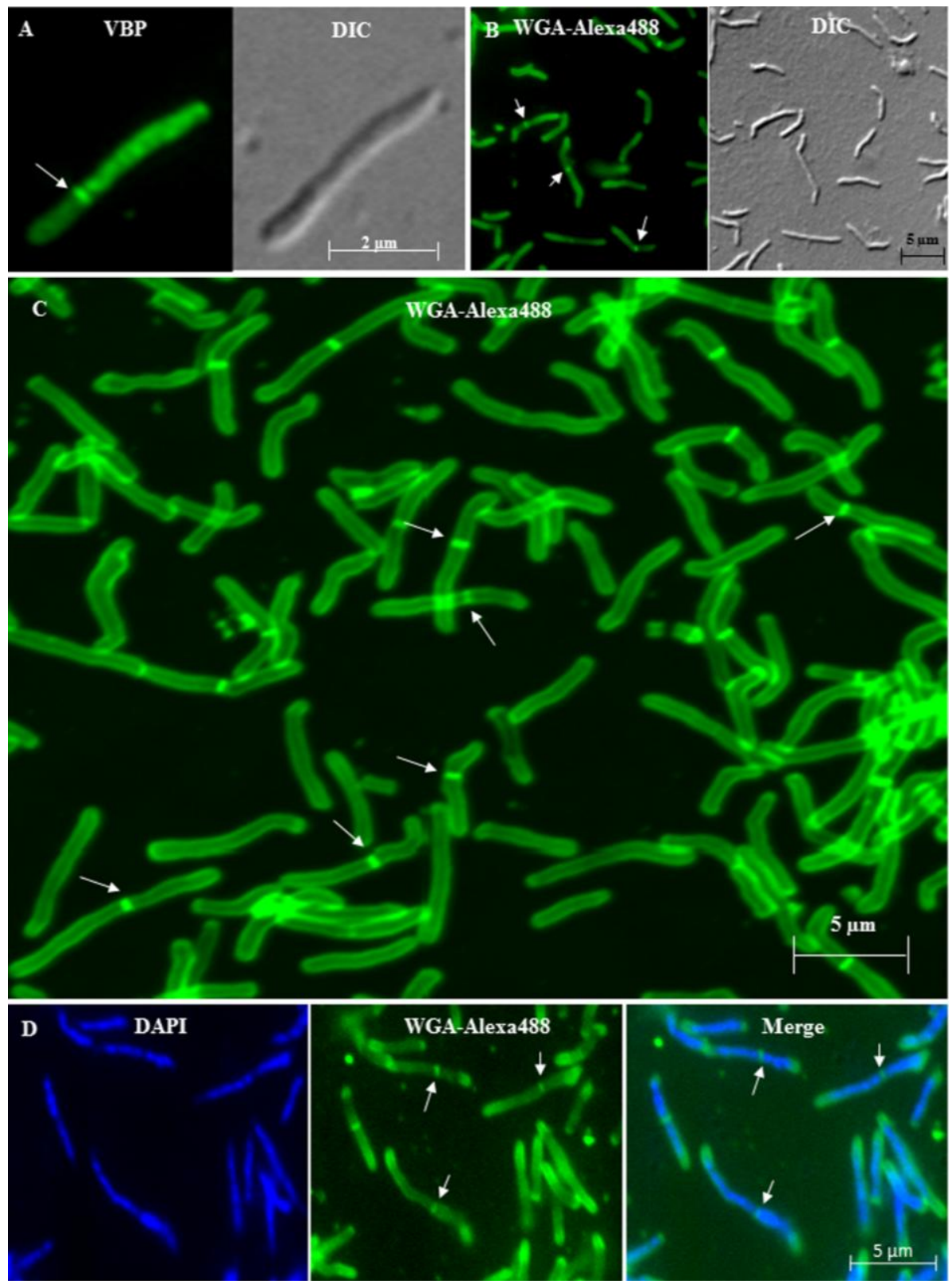

Fig. (3). Fluorescence imaging of mid-log phase live and fixed $M$. smegmatis and $M$. xenopi cells with asymmetric septum. (A). Fluorescence and the corresponding DIC image of the VBP stained live M. smegmatis cell with highly deviated asymmetric septum. (B). Fluorescence and the corresponding DIC image of the WGA-Alexa488 stained fixed M. smegmatis cell with highly deviated asymmetric septum. (C). Confocal image of fixed WGA-Alexa488 stained M. smegmatis cells with highly deviated asymmetric septum. (D). Highly deviated, asymmetrically dividing M. smegmatis cells stained with DAPI for nucleoid and WGA-Alexa488 for septum. The merge figure shows the WGA-Alexa488 stained septum dividing the DAPI stained nucleoids. In all the panels, the arrows indicate the position of the highly deviated asymmetric septum.

M. smegmatis dividing cells (by $1.11 \pm 0.01 \mu \mathrm{m} ; \mathrm{n}=50$ septating cells) (Table 1). The VBP and WGA-Alexa488 staining were also found towards the poles, probably indicative of the polar growth reported in mycobacteria $[11,17]$. Confocal microscopy of WGA-Alexa488 stained $M$. smegmatis cells confirmed the presence of highly deviated asymmetric septum in about $20 \%$ of the $15 \%$ septating $M$. smegmatis cells ( $\mathrm{n}=100$ septating cells) (Fig. 3C). Majority of the cells possessed symmetric septum, with minor deviation from the median (Fig. 3C).
Fluorescence imaging for DAPI-stained nucleoid and WGA-Alexa488 stained septum showed the presence of nucleoid both in the short and the long portions, on either side of the highly deviated asymmetric septum, in M. smegmatis cells ( $\mathrm{n}=100$ septating cells) (Fig. 3D). Like in the case of the TEM experiments, the average lengths of the $M$. smegmatis cells with asymmetric septum with major deviation $(5.10 \pm 0.64 \mu \mathrm{m} ; \mathrm{n}=50$ septating cells) or symmetric septum with minor deviation $(4.95 \pm 0.48 \mu \mathrm{m}$; $\mathrm{n}=50$ septating cells) were comparable (Table $\mathbf{1}$ ). 


\section{Live Cell Time-lapse Imaging Confirms Cell Division with Highly Deviated Constriction}

M. smegmatis cells $(\mathrm{n}=100)$ undergoing division with highly deviated constriction could be observed under live cell time-lapse imaging. An M. smegmatis mother cell was found to grow and divide symmetrically first, with minor deviation in the constriction position, to generate daughter cells of comparable lengths (Fig. 4). One of these daughter cells further grew and divided asymmetrically with a major deviation in the constriction position, close to the newly formed pole of the daughter cell, to generate a short cell and a long cell, with a high difference between their lengths. The other daughter cell underwent symmetric constriction, with minor deviation in the constriction position, to generate comparably sized daughter cells, with only minor difference in their lengths. One of these grand-daughter cells underwent symmetric division, with minor deviation in the constriction position, to generate daughter cells of comparable lengths. Thus, the comparably-sized first generation daughter cells, which were formed out of asymmetric division with minor deviation in the constriction position, took different pathways of division, one asymmetric with major deviation and the other symmetric with minor deviation in the division position. The cell lineages of the mother cell through the symmetric and asymmetric divisions are depicted in Fig. (5). Additional live cell time-lapse imaging of highly deviated asymmetric division of $M$. smegmatis cells also showed a long mother cell undergoing division to generate a short daughter cell and a long daughter cell, with major difference in their lengths (Fig. 6). The long daughter cell subsequently showed symmetric division with minor deviation, generating daughter cells of comparable lengths, whereas the short daughter cell was proceeding for asymmetric division (Fig. 6).

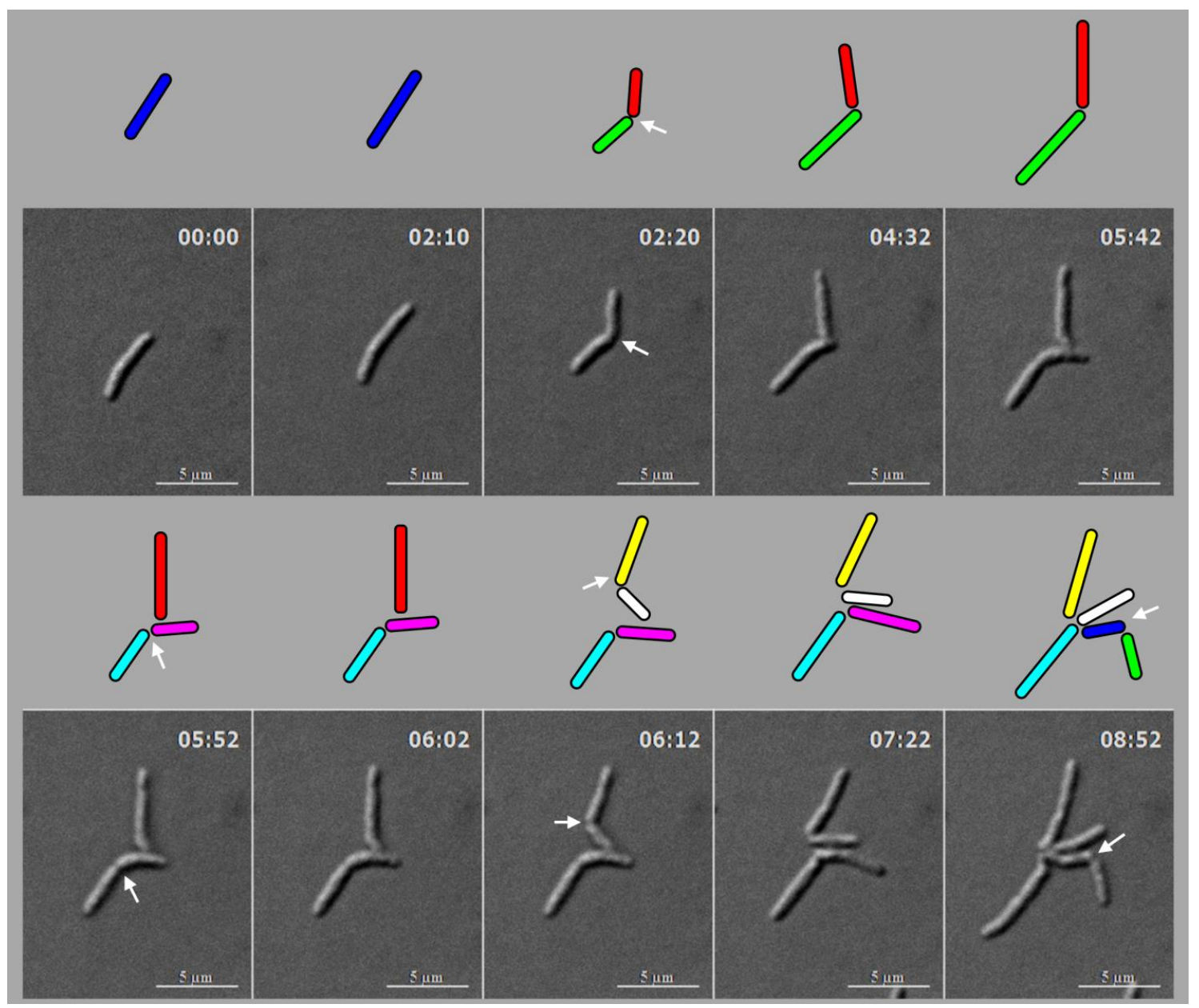

Fig. (4). Live cell time-lapse imaging of highly deviated asymmetric division of $M$. smegmatis cells, with colour cartoon for the cell images. Only minimum number of panels are shown just enough to depict the phenomenon. An M. smegmatis mother cell (blue) first underwent symmetric division to generate daughter cells of lengths, $3.08 \mu \mathrm{m}$ (red) and $3.20 \mu \mathrm{m}$ (green), with $0.12 \mu \mathrm{m}$ difference in their lengths. One of the daughter cells (red) further underwent asymmetric division, generating a short daughter cell ( $2.28 \mu \mathrm{m}$; white) and a long daughter cell $(3.66 \mu \mathrm{m}$; yellow), with $1.38 \mu \mathrm{m}$ difference in their lengths. The other daughter cell (green) underwent symmetric division, generating daughter cells of lengths, $4.06 \mu \mathrm{m}$ (pink) and $4.26 \mu \mathrm{m}$ (cyan), with $0.2 \mu \mathrm{m}$ difference between their lengths. One of these daughter cells (pink cell; $4.06 \mu \mathrm{m}$ ) further grew and underwent symmetric division to generate two daughter cells of lengths, $2.60 \mu \mathrm{m}$ (blue) and $2.87 \mu \mathrm{m}$ (green). Thus, the daughter cells of a symmetric division underwent two different modes of division. The growth rate of the short and the long cells of the asymmetric division were determined from the live cell imaging panels. 


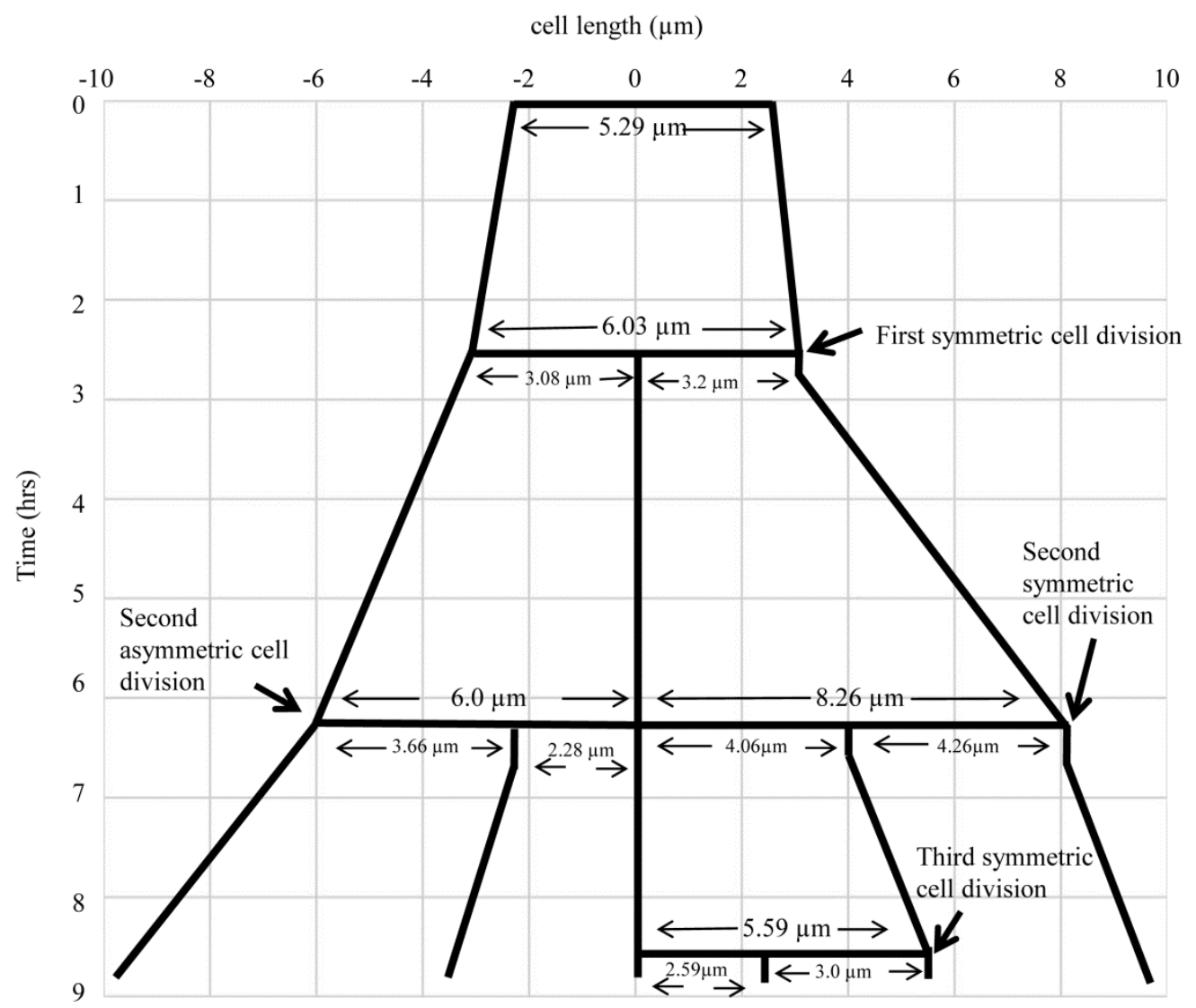

Fig. (5). The lineage of the growth and highly deviated asymmetric division of live $M$. smegmatis cell and of its daughter cells, shown in Fig. (4). The growth and division lineage was traced from the images of time-lapse microscopy in Fig. (4). The zero time point does not correlate with the birth of the starting mother cell.

The difference in the lengths between the short portion and the long portion of the asymmetrically constricting cells was $1.20 \pm 0.05 \mu \mathrm{m}(\mathrm{n}=50$ constricting cells) (Table $\mathbf{1})$. This amounted to a high extent of deviation of $12 \pm 5 \%$ ( $\mathrm{n}=50$ constricting cells) (Fig. 2) in the constriction position from the median. Major proportion $(80 \%)$ of the $M$. smegmatis cells showed symmetric constriction and division, with minor deviation of $3.6 \pm 2 \%(\mathrm{n}=50$ constricting cells) in their septum constriction (Fig. 2), to generate comparably-sized daughter cells, as reported for the cells in the majority population [2-4]. The short and the long cells of highly deviated asymmetric division showed comparable elongation rates of $0.80 \pm 0.20 \mu \mathrm{m}$ per $\mathrm{hr}$ ( $\mathrm{n}=100$ live cells). The generation time of the M. smegmatis cells, in both asymmetric and symmetric modes of division, during live cell time-lapse imaging, was $3 \mathrm{hr} 30 \mathrm{~min} \pm 30$ min. Thus, live cell time-lapse imaging confirmed asymmetric division with unusual constriction position deviation in M. smegmatis cells. Here it is important to note that the mean percentage deviation in the position of cell constriction (12 $\pm 5 \% ; \mathrm{n}=50$ constricting cells) is lesser compared to the extent of deviation in the position of the septum ( $17 \pm 4 \% ; \mathrm{n}=50$ septating cells) (Fig. 2). This could probably be due to polar growth, post-positioning of the septum, as reported [2-4]. Nevertheless, the extent of deviation was correspondingly much higher than the minor deviation seen in the position of the septum $(5 \pm 5 \% ; \mathrm{n}=50$ septating cells) or constriction $(3.6 \pm 2 \% ; \mathrm{n}=50$ constricting cells), in the majority of the population (Fig. 2). Taken together, these observations clearly show the unusually high deviation in the division site in the subpopulation of cells in the exponential phase cultures of both M. smegmatis and M. xenopi.

\section{DISCUSSION}

Revealing another facet of mycobacterial cell division, the present study shows for the first time in M. smegmatis and $M$. xenopi that asymmetric division with high deviation $(17 \pm 4 \%$ from the median) in the division site occurs in a very low proportion (20\%) of the septating cells in the population. SEM and septum-stained live and fixed cells, where the possibility of oblique cell sectioning was not involved unlike in TEM, and live cell time-lapse imaging of dividing cells confirmed the major deviation in the division site position during asymmetric division in these cells. The growth and division of $M$. smegmatis cells were not affected in agarose pad, as the division time of $M$. smegmatis cells in the agarose pad in the live cell time-lapse imaging experiments ( $3 \mathrm{hr} 30 \mathrm{~min} \pm 30 \mathrm{~min}$ ) was comparable to that reported for $M$. smegmatis cells in shaking cultures in liquid medium [18]. Further, the presence of low proportion of highly deviated asymmetric cell division in cultures, with or 


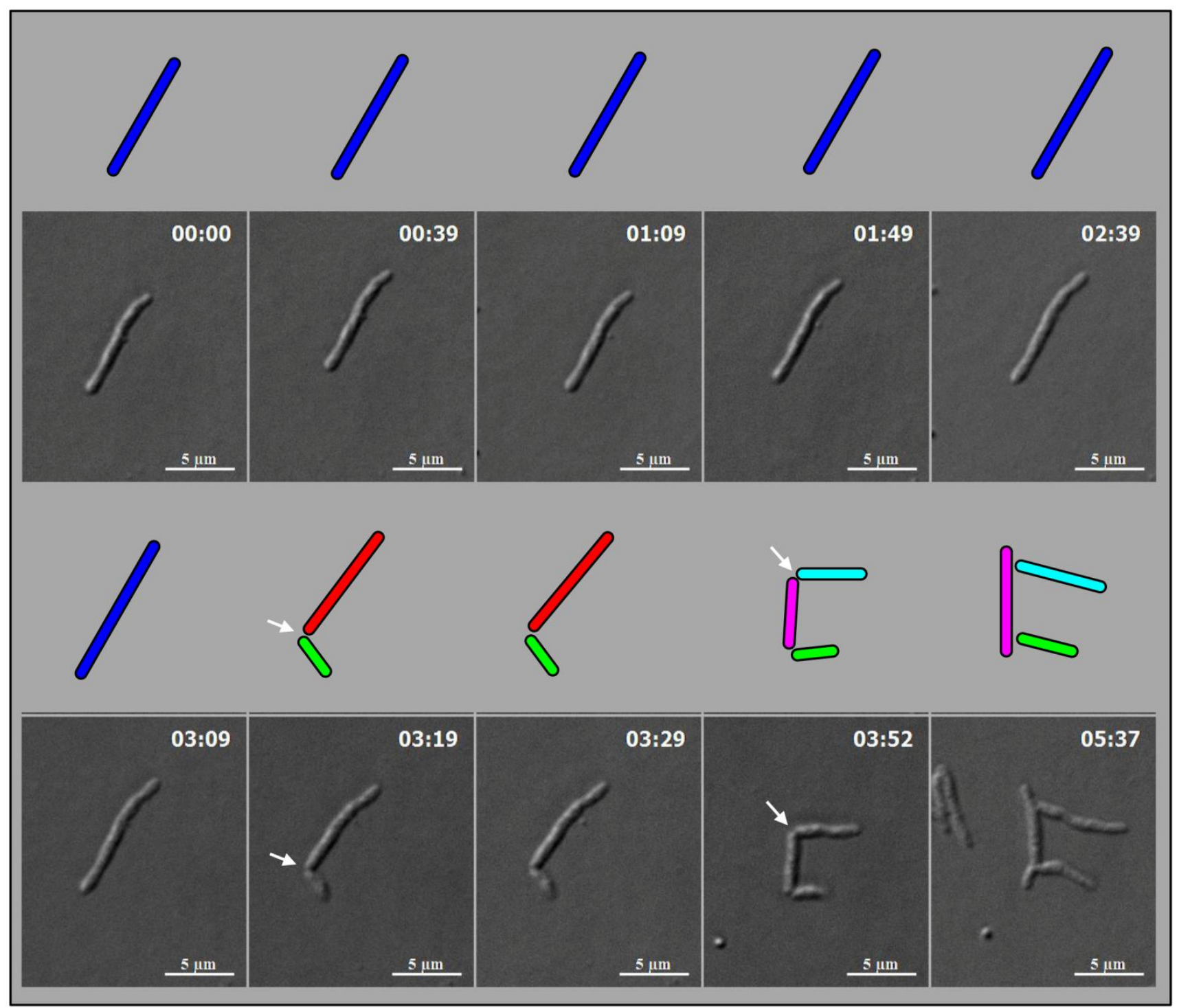

Fig. (6). Live cell time-lapse imaging of highly deviated asymmetric division of mid-log phase M. smegmatis long mother cell. An M. smegmatis long mother cell (blue cell; $9.79 \mu \mathrm{m}$ ) first underwent highly deviated asymmetric division close to one pole (arrow), to generate a short daughter cell (green cell, $2.67 \mu \mathrm{m}$ ) and a longer-sized daughter cell (red cell, $7.84 \mu \mathrm{m}$ ), with the difference of $5.17 \mu \mathrm{m}$ in their lengths. The longer-sized daughter cell (red cell, $7.84 \mu \mathrm{m}$ ) subsequently showed symmetric division with minor deviation (arrow), generating daughter cells of lengths, $4.59 \mu \mathrm{m}$ and $4.36 \mu \mathrm{m}$ (pink and cyan cells), with the difference of $0.23 \mu \mathrm{m}$ in length between them. The images were observed under DIC. Arrows indicate the site of cell constriction at asymmetric or symmetric position.

without Tween 80, showed that Tween 80 did not affect the proportion of cells undergoing unusually deviated asymmetric division.

Very recently, we have shown that low proportions of mid-log phase population of Mycobacterium tuberculosis cells also undergo division with highly deviated division position [15]. Interestingly, more than three decades ago, the presence of $M$. smegmatis cells with asymmetric septum could be found in the TEM imaging performed, although it went unreported [see Fig. 10A in 19]. About two decades later, a study using scanning electron microscopy also showed short daughter cells breaking off from long M. tuberculosis mother cells, which suggested asymmetric septation as one of the possibilities [17]. The cell division with highly deviated septum position in the low proportions of M. smegmatis, M. xenopi, and M. tuberculosis cells indicate that it may be a trait common to both pathogenic and non-pathogenic mycobacterial species. It may be noted here that such highly deviated asymmetric division in the low proportions of exponentially growing $M$. tuberculosis, $M$. smegmatis and $M$. xenopi cells is very different in many ways from the symmetric mode of division with minor (5-10\%) deviation in the division site position, in the cells in the majority population reported [2-4]. First of all, the highly deviated asymmetric division occurs in the minority population, whereas the symmetric division with minor deviation occurs in the majority of the population. Secondly, the highly deviated asymmetric division generates significant cell size heterogeneity in the population, unlike the 
symmetric division with minor deviation. Thirdly, there does not seem to be any compensatory mechanism to counter the high deviation in the asymmetric division, unlike reported for the symmetric division with minor deviation [3].

One of the studies on symmetric division with minor deviation showed that the septum placement is accurately symmetric at the mid-cell site, but differential growth from the cell tips generates an apparent minor asymmetricity [2]. Another study showed that FtsZ ring placement is asymmetric in $50 \%$ of the cells but differential polar growth compensates to generate predominantly symmetric division [3]. However, in our study, the mechanism responsible for the major deviation in the division site position remains to be determined. The MinCDE systems [20-22], which are the bacterial toporegulators of septum placement, are absent in mycobacteria [1]. Interestingly, in spite of the absence of MinCDE, the asymmetric division with major deviation occurs only in a specific low proportion of the population, instead of in a randomised manner expected. The consistent maintenance of highly deviated asymmetric division in $20 \%$ of the septating population of cells alludes to the possibility that it may be a regulated and a committed event in the population, to generate short cells and long cells for creating cell size heterogeneity. Since both the pathogenic and the non-pathogenic mycobacterial species generate cell size heterogeneity through highly deviated asymmetric division, it seems to be of physiological importance common to both the species types.

Nucleoid occlusion systems, such as Noc [23] and SImA [24] are absent in both Mycobacteria [1] and Corynebacteria [25], which are closely related Actinobacteria. However, TEM and DAPI-stained images showed that the positioning of the septum in the asymmetric and symmetric division was found in the space between the already asymmetrically or symmetrically segregated nucleoids, respectively. Thus, the positioning of the septum in the asymmetric division with major deviation and symmetric division with minor deviation was in accordance with the nucleoid occlusion principle [26]. Recent studies in Corynebacterium glutamicum have shown that asymmetric division site selection is spatially and temporally regulated by nucleoid segregation [27]. Mutants defective in nucleoid segregation machinery led to nucleoid guillotining by division septum and generation of anucleated cells [27], thereby implicating a role for nucleoid segregation and nucleoid occlusion phenomenon in asymmetric septum formation. These studies on the nucleoid segregation in C. glutamicum support our observations on the nucleoid occlusion phenomenon during the highly deviated asymmetric cell division in the minority population in $M$. smegmatis and $M$. xenopi cells in the present study and in $M$. tuberculosis cells, as already reported [15].

Phenotypic heterogeneity, especially the presence of short M. smegmatis cells, has been found under stress conditions, such as nutrient depletion [28, 29]. The proportion of short M. smegmatis cells has been found to gradually increase as the culture approached stationary phase $[11,29]$, which is characterised by nutrient depletion stress. These stationary phase short cells are most likely to be different from the short cells generated by the highly deviated asymmetric division, as the former are stresstolerant and present under nutrient stress condition, while the latter are present under stress-free actively growing, nutrientenriched condition. Phenotypically heterogeneous populations of $M$. tuberculosis have also been found in patient samples [30] and in mouse and guinea pig lung tissues [31], and of Mycobacterium scrofulaceum in generalised mycobacteriosis [32]. However, in spite of these several instances of the occurrence of phenotypic heterogeneity, the mechanism of generation of phenotypic heterogeneity in mycobacterial population remains largely unknown. It is possible that the increase in the number of short cells in the progression towards stationary phase may be through the increasing number of cells undergoing highly deviated asymmetric division and/or through simple size reduction due to decreasing availability of nutrients. Nevertheless, the highly deviated asymmetric division seems to be one of the several mechanisms adopted by mycobacteria to generate cell size heterogeneity in the population.

The presence of phenotypically different forms of different mycobacterial species under diverse stress conditions, such as the high proportion of M. smegmatis short cells in the nutrient-starved stationary phase [28, 29], acid-fastness-lost variants of $M$. tuberculosis, Mycobacterium kansasii, and Mycobacterium phlei under extreme starvation conditions [28], spore-like forms of M. smegmatis, M. marinum, M. bovis [33], and M. avium Subsp. Paratuberculosis [34] under chronically starved and aged conditions, the ovoid- or the coccoid-shaped $M$. tuberculosis [35] and M. smegmatis [36] cells under extreme nutrient stress conditions, L-forms of M. phlei [37], $M$. scrofulaceum [32], and M. tuberculosis [38] under stress conditions, and the presence of short $M$. tuberculosis cells in the sputum of freshly diagnosed pulmonary tuberculosis patients [15] show that there seems to be a strong correlation between phenotypic heterogeneity in the mycobacterial population and stress tolerance. Interestingly, drugsusceptible and MDR samples have been found to contain asymmetrically dividing tubercle bacilli, the proportion of which was found to increase in the XDR and XXDR samples [39]. Recently, it was found that about $50 \%$ of Helicobacter pylori cells, a human pathogen, divide asymmetrically, with more than $10 \%$ deviation from the median [40]. M. xenopi, which was found to undergo highly deviated asymmetric division in our study, is a pathogen isolated from the skin lesions of Xenopus laevis [6]. Recently, presence of $M$. xenopi has also been detected in humans with tuberculosislike disease symptoms [41], indicating that it can survive in the human system also. Similarly, although M. smegmatis is considered to be a saprophyte, it was originally isolated from human smegma [42], and therefore the bacilli can possibly tolerate the stress conditions therein. Thus, taken together, the highly deviated asymmetric cell division in the saprophytic M. smegmatis (isolated from humans), and in the human pathogens, M. tuberculosis and $H$. pylori, and in the human-infectible $M$. xenopi, alludes to the strong possibility that the heterogeneous sub-population generated by the highly deviated asymmetric division in these bacilli may 
have a role in their survival under diverse stress conditions, both inside and outside the host systems.

\section{CONFLICT OF INTEREST}

The authors confirm that this article content has no conflict of interest.

\section{ACKNOWLEDGEMENTS}

This work was supported in part by part-grants from the DBT supported Centre of Excellence in Tuberculosis Research and IISc-DBT Partnership Programme to PA. Authors acknowledge infrastructure support from the IISc-DBT Partnership Programme, DST-FIST and UGCCAS in the MCB Dep't, and from IISc. Authors thank E. Rajasegaran for technical help in SEM, Ms. Samrajyam Nara for help in confocal microscopy, and Dr. Indi and P. V. Balasubramaniam for help in TEM. SV acknowledges CSIR Senior Research Fellowship. MN acknowledges research fellowship from IISc.

\section{REFERENCES}

[1] Hett EC, Rubin EJ. Bacterial growth and cell division: A Mycobacterial perspective. Microbiol Mol Biol Rev 2008; 72: 126-56.

[2] Joyce G, Williams KJ, Robb M, et al. Cell division site placement and asymmetric growth in mycobacteria. PLoS ONE 2012; 7: e44582. doi: 10.1371/journal.pone.0044582.

[3] Singh B, Nitharwal RG, Ramesh M, Pettersson BMF, Kirsebom LA, Dasgupta S. Asymmetric growth and division in Mycobacteria spp: Compensatory mechanisms for non-medial septa. Mol Microbiol 2013; 88: 64-76.

[4] Santi I, Dhar N, Bousbaine D, Wakamoto Y, McKinney JD. Single-cell dynamics of the chromosome replication and cell division cycles in mycobacteria. Nature Commun 2013; 4: 2470. doi:10.1038/ncomms3470.

[5] Snapper SB, Melton RE, Mustafa S, Kieser T, Jacobs WR Jr. Isolation and characterisation of efficient plasmid transformation mutants of Mycobacterium smegmatis. Mol Microbiol 1990; 4: 1911-1919.

[6] Schwabacher H. A strain of Mycobacterium isolated from skin lesions of a cold-blooded animal, Xenopuslaevis, and its relation to atypical acid-fast bacilli occurring in man. J Hyg (Lond) 1959; 57: 57-67.

[7] Takade A, Takeya K, Taniguchi H, Mizuguchi, Y. Electron microscopic observations of cell division in Mycobacterium vaccae V 1. J Gen Microbiol 1983; 129: 2315-20.

[8] Vijay S, Anand D, Ajitkumar P. Unveiling unique features of formation of septal partition and constriction in mycobacteria - an ultrastructural study. J Bacteriol 2012; 194: 702-7.

[9] Reynolds PE. Structure, biochemistry and mechanism of action of glycopeptide antibiotics. Eur J Clin Microbiol Infect Dis 1989; 8: 943-50.

[10] Daniel RA, Errington J. Control of cell morphogenesis in bacteria: Two distinct ways to make a rod-shaped cell. Cell 2003; 113: 76776.

[11] Thanky NR, Young DB, Robertson BD. Unusual features of the cell cycle in mycobacteria: Polar-restricted growth and the snapping-model of cell division. Tuberculosis 2007; 87: 231-6.

[12] Sizemore RK, Caldwell JJ, Kendrick AS. Alternate Gram-staining technique using a fluorescent lectin. Appl Env Microbiol 1990; 56: 2245-7.

[13] de Jong IG, Beilharz K, Kuipers OP, Veening JW. Live cell imaging of Bacillus subtilis and Streptococcus pneumoniae using automated time-lapse microscopy. J Vis Exp 2011; 53: e3145. doi: $10.3791 / 3145$ (2011).

[14] Joyce G, Robertson BD, Williams KJ. A modified agar pad method for mycobacterial live-cell imaging. BMC Res Notes 2011; 4: 73. doi: 10.1186/1756-0500-4-73.
[15] Vijay S, Nagaraja M, Sebastian J, Ajitkumar P. Asymmetric cell division in Mycobacterium tuberculosis and its unique features. Arch Microbiol 2014; 196: 157-68.

[16] Rasband WS. ImageJ, U. S. National Institute of Health, Bethesda. 2012; http://imagej.nih.gov/ij/

[17] Dahl JL. Electron microscopy analysis of Mycobacterium tuberculosis cell division. FEMS Microbiol Lett 2004; 240: 15-20.

[18] Newton GL, Unson MD, Anderberg SJ, et al. Characterisation of Mycobacterium smegmatis mutants defective in 1-D-myo-Inosityl2-amino-2-deoxy-a-D-glucopyranoside and mycothiol biosynthesis. Biochem Biophys Res Commun 1999; 255: 239-44.

[19] Barksdale L, Kim KS. Mycobacterium. Bacteriol Rev 1977; 41: 217-372.

[20] de Boer PAJ, Crossley R, Rothfield L. A division inhibitor and a topological specificity factor coded for by the mini-cell locus determine proper placement of the division septum in E. coli. Cell 1989; 56: 641-9.

[21] Yu XC, Margolin W. FtsZ ring clusters in min and partition mutants: Role of both the Min system and the nucleoid in regulating FtsZ ring localisation. Mol Microbiol 1999; 32: 315-26.

[22] Lutkenhaus J. Assembly dynamics of the bacterial MinCDE system and spatial regulation of the Z-ring. Ann Rev Biochem 2007; 76: 539-62.

[23] Wu L, Errington J. Coordination of cell division and chromosome segregation by a nucleoid occlusion protein in Bacillus subtilis. Cell 2004; 117: 915-25.

[24] Bernhardt TG, de Boer PAJ. SlmA, a nucleoid-associated, FtsZ binding protein required for blocking septal ring assembly over chromosomes in E. coli. Mol Cell 2005; 18: 555-64.

[25] Letek M, Fiuza M, Ordónez E, et al. Cell growth and cell division in the rod-shaped actinomycete, Corynebacterium glutamicum. Antonie van Leewenhoek 2008; 94: 99-109.

[26] Woldringh CL, Mulder E, Valkenburg JAC, Wientjes FB, Zaritsky A, Nanninga $\mathrm{N}$. Role of the nucleoid in the toporegulation of division. Res Microbiol 1990; 141: 39-49.

[27] Donovan C, Schauss A, Kramer R, Bramkamp M. Chromosome segregation impacts on cell growth and division site selection in Corynebacterium glutamicum. PLoS ONE 2013; 8: e55078. doi:10.1371/journal.pone.0055078.

[28] Nyka W. Studies on the effect of starvation on mycobacteria. Infect Immun 1974; 9: 843-50.

[29] Smeulders MJ, Keer J, Speight RA, Williams HD. Adaptation of Mycobacterium smegmatis to stationary phase. J Bacteriol 1999; 181: $270-83$

[30] Khomenko AG. The variability of Mycobacterium tuberculosis in patients with cavitary pulmonary tuberculosis in the course of chemotherapy. Tubercle 1987; 66: 243-53.

[31] Ryan GJ, Hoff DR, Driver ER, et al. Multiple M. tuberculosis phenotypes in mouse and guinea pig lung tissue revealed by a dualstaining approach. PLoS ONE 2010; 5: e11108.

[32] Korsak T. Occurrence of L-forms in a case of generalised mycobacteriosis due to Mycobacterium scrofulaceum. Acta Tuberc Pneumol Belg 1975; 66: 445-69.

[33] Ghosh J, Larsson P, Singh B, et al. Sporulation in mycobacteria. Proc Natl Acad Sci USA 2009; 106: 10781-6.

[34] Lamont EA, Bannantine JP, Armien A, Ariyakumar DS, Sreevatsan $\mathrm{S}$. Identification and characterisation of a spore-like morphotype in chronically starved Mycobacterium avium Subsp. Paratuberculosis cultures. PLoS ONE 2012; 7: e30648.

[35] Shleeva MO, Bagramyan K, Telkov MV, et al. Formation and resuscitation of "nonculturable" cells of Rhodococcus rhodochrous and Mycobacterium tuberculosis in prolonged stationary phase. Microbiology 2002; 148: 1581-91.

[36] Shleeva MO, Mukamolova GV, Young M, Williams HD, Kaprelyants AS. Formation of "nonculturable" cells of Mycobacterium smegmatis in stationary phase in response to growth under suboptimal conditions and their Rpf-mediated resuscitation. Microbiology 2004; 150: 1687-97.

[37] Imaeda T. Ultrastructure of L-phase variants isolated from a culture of Mycobacterium phlei. J Med Microbiol 1975; 8: 389-95.

[38] Markova N, Michailova L, Jourdanova M, et al. Exhibition of persistent and drug tolerant L-form habit of Mycobacterium tuberculosis during infection in rats. Cent Eur J Biol 2008; 3: 407-16. 
[39] Farnia P, Masjedi MR, Merza MA, et al. Growth and cell-division in extensive (XDR) and extremely drug resistant (XXDR) tuberculosis strains: Transmission and atomic force observation. Int J Clin Exp Med 2010; 3: 308-14.

[40] Specht M, Dempwolff F, Schatzle S, Thomann R, Waldner B. Localisation of FtsZ in Helicobacter pylori and consequences for cell division. J Bacteriol 2013; 195: 1411-20.
[41] Satyanarayana G, Heysell SK, Scully KW, Houpt ER. Mycobacterial infections in a large Virginia hospital, 2001-2009. BMC Infect Dis 2011; 11: 113. doi:10.1186/1471-2334-11-113.

[42] Alvarez E, Tavel E. Recherchessur le bacille' de Lustgarden. Arch Physiol Normale Pathol 1885; 6: 303-21.

Received: February 8, 2014

Revised: March 8, 2014

Accepted: April 7, 2014

(C) Vijay et al.; Licensee Bentham Open.

This is an open access article licensed under the terms of the Creative Commons Attribution Non-Commercial License (http://creativecommons.org/licenses/by-nc/3.0/) which permits unrestricted, non-commercial use, distribution and reproduction in any medium, provided the work is properly cited. 